Exp. Anim. 39(4), 571-575, 1990

\title{
Visual Function of Cynomolgus Monkeys with Macula Degeneration and Peripheral Retinal Degeneration
}

\author{
Michihiro T. SUZUKI, Hiromi OGAWA, Fumiaki CHO*, and Shigeo HONJO* \\ The Corporation for Production and Research of Laboratory Primates and \\ * Tsukuba Primate Center for Medical Science, The National Institute \\ of Health, 1 Hachimandai, Tsukuba-shi, Ibaraki 305, Japan
}

(Received 23 March 1990/Accepted 11 May 1990)

\begin{abstract}
Using the simplified method for judging visual function of the cynomolgus monkey that was established by the present authors (Suzuki et al., 1988), forty-four cynomolgus monkeys with normal ophthalmoscopic findings, eleven monkeys with macula degeneration and thirteen monkeys with peripheral retinal degeneration were examined for their visual function. It was demonstrated that the monkeys with macula degeneration were inferior in their visual function to the monkeys with normal fundus. In addition, the degree of visual function varied with the degree of macula degeneration. The monkeys with peripheral retinal degeneration showed about the same degree in their visual function as the monkeys with normal fundus.
\end{abstract}

\section{黄斑変性および非中心性網膜変性を呈した カニクイザルの視覚機能}

鈴木通弘・小川浩美・長 文昭*・本庄重男*

社団法人予防衛生協会

*国立予研筑波医学実験用霊長類センター

我々はこれまでにカニクイザルの眼科学的検査法のひ とつとして眼底検査を取り上げ，加龄に伴う眼底像の 変化や自然発生性異常所見について報告してきた $[9 \sim$ $15]$ 。我々はまた，簡単で実用的なカニクイザルの視覚 判定法を開発した $[16]$ 。それは, 光透過率が異なる面 を着用した人の眼に対するカニクイザルの凝視反応を利 用する方法である。本論文は，その方法により，黄斑変 性個体と非中心性網膜変性個体の視覚機能を調査した成 樍を報告するものである。

\section{材料および方法}

筑波医学実験用霊長類センターで飼育されている, 野 生由来48頭（倠33頭, 雄15頭) ならびに 5 歳龄から14歳 龄の育成カニクイザル20頭（雌19頭, 雄 1 頭）の計68頭
を使用した。その内訳は，前眼部および眼底の所見が正 常 (Fig. 1) なもの44頭と両眼の黄斑部に非常に細か い灰白色から黄白色の斑点（Fig. 2) が $5 \sim 8$ 個（軽 度) から約20個 (中度) 認められる11頭 (黄斑变性), 両眼の網膜周辺部に非常に細かい灰白色ないし黄白色の 斑点 (Fig. 3) が約30ヶ以上認められる13頭（非中心 性網膜変性）である。これらの個体は総て，その他の点 で, 視診, 触診により, 健康と判断されたるのである。

検査方法については前報 [16] と同様であるが，以下 に簡単に記載する。検査を行った室には, 約 160 頭のカ ニクイザルが個別ケージで飼育されている。その環境条 件は, $100 \%$ 新鮮空気が供給され, 室温 $25 \pm 2{ }^{\circ} \mathrm{C}$, 湿度 $60 \pm 10 \%$, 換気回数 10 回/時, 照明時間 14 時間/日, ヶー シ前面の照度650～750ルックスに，設定されている $[3$, $4]$ 。 


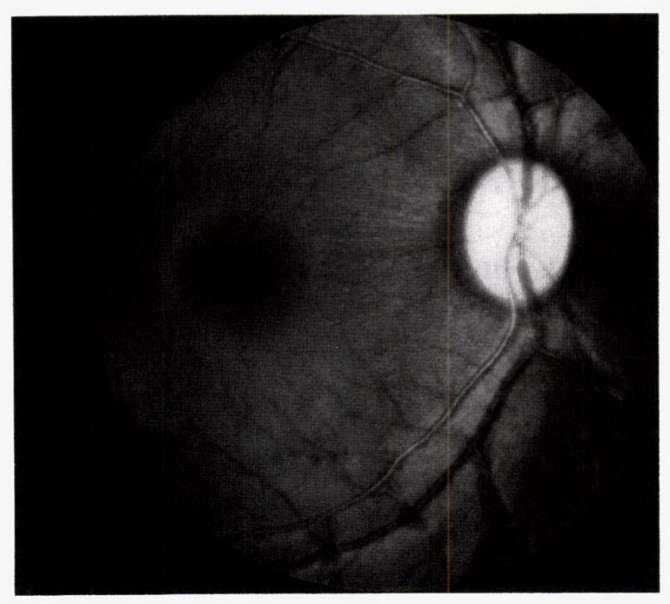

Fig. 1. Typical picture normal ocular fundus in cynomolgus monkeys

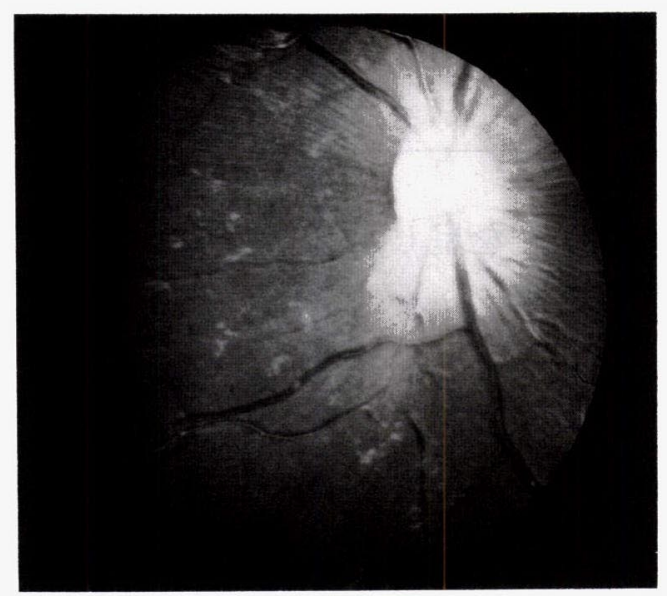

Fig. 3. Peripheral retinal degeneration of a cynomolgus monkey

検査者の服装は, 動物室で着用する通常の作業着とし た。すなわち, 頭巾, マスク, 綿製つなぎ服, ビニール 製前掛け, ゴム長靴, ゴム手袋，ビニール腕カバーを着 用し、さらに透明プラスチック製ゴグルを装着するもの である $[3,4]$ 。

透明プラスチック製ゴグルには，以下のごとさ処理を 加えた。まず，マスクが見える部分（ゴグルの下側 2 I 3) に光透過率 $20 \%$ のニニーラルデンシティーフィル ター（富士写真フィルム製, 以下, NDフィルターと略 記）を貼付し，ゴグルを着用した場合，外部からは眼周 囲のみがみえるようにした。次いで、ゴグルの上側 1 / 3 に, 各段階の光透過率を有する NDフィルターを貼

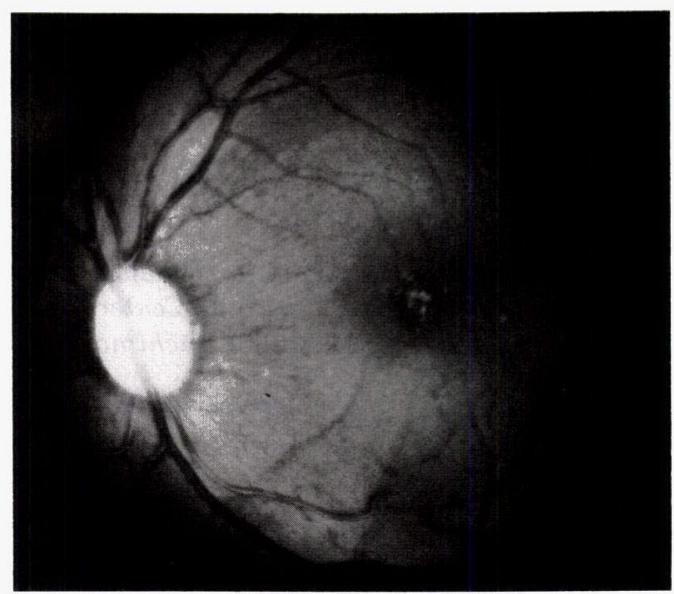

Fig. 2. Macula degeneration of a cynomolgus monkey

付した。光透過率10\%の NDフィルターを貼付した場 合, ゴグルを着用した人の眼を，外部から識別すること は困難である。但し，着用者は外部を識別できる。

検査は, 被検個体収容のケージ前面に, 検査者 2 名が ケージを向いて位置し, 内 1 名（以下A）は, 対照とし て光透過率 $10 \%$ ND フィルター貼付ゴグルを常に着用 し, 他の 1 名 (以下B) は, $100,80,65,50,40,30$, 20, $10 \%$ の各透過率の ND フィルター貼付ゴグルを着用 した。なお，ゴグル非着用の場合も併せて検査例に加え た。上記 2 名は被検サルに顔をみせないよらにあらかじ め下側を向いて対し, 次いで, 1 名が他者の体にェンピ ッもしくは手指等で軽く接触・合図し, それと同時に 2 名が顔を上げ被検個体に対面する。この際, ケージ前面 からゴグルの距離は約 $25 \mathrm{~cm}$ とした。ここで, 被検サル がBの眼を擬視する行動をとるか否かを記録した。ここ での凝視とは, 被検サルと人が対面し, 被検サルが人の 眼を注視することである。判定は人が顔を上げた後 5 秒 以内に凝視行為を示した場合に限り，1個体につき，光 透過率の各段階，すなわち，100\%～10\%の ND フィル ター貼付ゴグルを着用しての検査を 1 クールとし, 各 $\mathrm{ND}$ フィルター貼付ゴグル着用の順位はランダムとし た。この観察を 1 個体当り 5 クール扣こなった。総検査 所要時間は 1 頭当りゴグル着脱時間を含め約20分であっ た。

視覚機能の良否の判定は, 同一透過率のフィルターに 抢いて, 5 回中 4 回以上凝視した場合, 視覚機能良好之 判定し, 5 回中 3 回以下では視界機能不良とした [16]。 
Table 1. Summary of the results of visual function test in Cynomolgus monkeys

\begin{tabular}{|c|c|c|c|c|}
\hline ND filter & $\begin{array}{l}\text { Transparency } \\
\text { rate of } \\
\text { ND filter }\end{array}$ & $\begin{array}{l}\text { Monkeys with } \\
\text { normal ocular } \\
\text { fundus }\end{array}$ & $\begin{array}{l}\text { Monkeys with } \\
\text { macula } \\
\text { degeneration }\end{array}$ & $\begin{array}{l}\text { Monkeys with } \\
\text { peripheral retinal } \\
\text { degeneration }\end{array}$ \\
\hline$(-)$ & $100 \%$ & $38^{*}$ & 10 & 11 \\
\hline \multirow{8}{*}{$(+)$} & $100 \%$ & 38 & 10 & 11 \\
\hline & $80 \%$ & 38 & 9 & 11 \\
\hline & $65 \%$ & 38 & 1 & 11 \\
\hline & $50 \%$ & 32 & 1 & 9 \\
\hline & $40 \%$ & 16 & 0 & 3 \\
\hline & $30 \%$ & 2 & 0 & 1 \\
\hline & $20 \%$ & 0 & 0 & 0 \\
\hline & $10 \%$ & 0 & 0 & 0 \\
\hline \multicolumn{4}{|c|}{ No. of monkeys } & 11 \\
\hline
\end{tabular}

* : No. of monkeys which looked into the eyes of observer wearing a face hood with a sheet of ND filter paper attached $\quad * *$ : Nine other animals were tested but they were disturbed by a monkey kept in the adjacent cage during the test, and were excluded from this table.

Table 2. Summary of the results of visual function test in cynomolgus monkeys with macula degeneration

-Relationship between grade of macula degeneration and visual function-

\begin{tabular}{cccc}
\hline ND filter & $\begin{array}{l}\text { Transparency rate } \\
\text { of ND filter }\end{array}$ & $\begin{array}{l}\text { Monkeys with } \\
\text { Grade } 1(+)^{*}\end{array}$ & $\begin{array}{l}\text { macula degeneration } \\
\text { Grade 2(+ })^{* *}\end{array}$ \\
\hline$(-)$ & $100 \%$ & 6 & 4 \\
\hline $100 \%$ & 6 & 4 \\
$80 \%$ & 6 & 3 \\
$(+)$ & $65 \%$ & 1 & 0 \\
& $50 \%$ & 1 & 0 \\
& $40 \%$ & 0 & 0 \\
& $30 \%$ & 0 & 0 \\
$20 \%$ & 0 & 0 \\
\hline
\end{tabular}

No. of monkeys

examined $^{* * *} \quad 6 \quad 4$

${ }^{*}$ : Grade $1(+)$ : Five to 8 small hypopigmented spot were observed in the macula region. $\quad{ }^{* *}$ : Grade $2(+)$ : About 20 small hypopigmented spot were observed in the macula region. $\quad{ }^{* * *}$ : Another animal was tested but during the test he was disturbed by a monkey kept in the adjacent cage during the test, and was excluded from this table.

成

被検個体68頭中59頭（87\%）で本法による検査が可能 であった(Table 1)。すなわち, 被検カニクイザルは, 検査者 2 名 (A， B ）のうち, 前方外部より眼を透視し 得る Bの方を向き，その眼を凝視した。しかし， A， B 両名が $10 \% \mathrm{ND}$ フィルター貼付ゴグルを着用した際は， 両名の眼を何れも凝視することなく，ケージ内を回転
し，あるいは毛づくろいを行い,もしくはケージ側壁を 向くなどの行動をとった。あるいは, 偶発的に検査者の 方向をみることも記録されたが，検査者の眼を凝視する ことはなく、ゴグルの上側，もしくは下側を見る行動が 記録された。

Table 1 に, 本法による検査が可能であった 59 頭に おける検査結果を示す。眼底所見正常ザル38頭について は, 光透過率65\%までの基準で, 全例が視覚機能良好と 
判定された。しかし，光透過率50\%の基準で 6 頭，同じ く40\%の基準では22頭，30\%の基準で36頭がそれぞれ視 覚機能不良と判定され，光透過率20\%の基準では，全例 が視覚機能不良と判定された。一方，両眼に黄斑変性所 見の認められた10頭では，光透過率80\%の基準で 1 頭が 視覚機能不良と判定され，光透過率65\%の基準で 9 頭, 残りの 1 頭も光透過率 $40 \%$ の基準で視覚機能不良と判定 された。両眼に非中心性網膜变性所見の認められた11頭 では，光透過率65\%までの基準で，全例が視覚機能良好 と判定された。しかし, 光透過率50\%の基準で 2 頭が, 同じく40\%の基準では 8 頭，30\%の基準では10頭が視覚 機能不良と判定され，光透過率20\%の基準では，全例が 視覚機能不良と判定された。さらに，黄斑変性の程度別 における視覚機能についてみると，Table 2 に示した ように，黄斑変性が軽度と判定された 6 頭では，光透過 率80\%の基準までは，全例が視覚機能良好と判定され， 光透過率65\%の基準では 5 頭が視覚機能不良と判定され た。光透過率40\%の基準では, 全例が視覚機能不良と判 定された。黄斑変性中度と判定された 4 頭では，80\%の 基準で 1 頭が視覚機能不良と判定され，残りの 3 頭も， 光透過率65\%の基準で視覚機能不良と判定された。

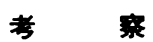

動物の視覚機能の評価に応用される検査法には，ま ず，網膜活動電位や視覚誘発電位の測定による方法があ る [2]。その他の検査法としては, 検査者の手指もしく は検查者が物体を被検動物の眼前を通過させ, 瞬目反射 を記録する方法や，障害コースを歩行させ，その反応を 記録・判定する方法が行われている $[1,17]$ 。これらの 方法は，何れも，あっぱら定性的な検査法である。視覚 機能を定量的に評価する方法としては, ラットにおいて 簡易検出法が考案され，実施されている $[5,6]$ 。また， オペラントの学習訓練を用いた視覚弁別学習検査も報告 されている [7]。これは, 動物の条件行動を応用し, 学 習能力に及ぼす影響を視覚を媒介として検査するもの で，サル類では，ウィスコンシン汎用テスト装置や，ス キナーボックスによる方法が広く用いられている[7]。 しかし、これらの方法は, 視覚機能に異常のある個体を 対象とする場合, 訓練自体が困難なことや，視覚機能の 正常な動物においても，予備訓練に時間を要する点で, 尽速な臨床診断のための視覚機能検査法としては, 実用 性にとぽしいと思われる。

我々が考案した人の眼に対するカニクイザルの凝視反 応を利用する視覚機能判定法は [16], 人とカニクイザ
ルが正面で対峙した際，カニクイザルが人の眼を凝視す る性質を利用したものである。従って，検査のための予 備訓練を特に必要としない。さらに, この方法では人の 眼周囲を，いろいろな程度の光透過率をすつ ND > ルターにより減光し，凝視行為の条件に，段階を付して いるので，結果をある程度定量的に示すことが可能であ る。本法は, 視覚機能のらち, 単に明暗識別能を検査し ているにとどまるが，視覚機能のスクリーニング検査と して有用であろう。

ところで，今回示した成績についてみると，被検個体 の約 1 割で，本法による検査を行らことが不可能であっ た。この原因のひとつは，160頭ものカニクイザルを個 別ヶージで飼育している室で検査を実施したため，検査 開始後, 被験個体の隣にいるカニクイザルがケージをゆ すったり，床から手を出したりしたことにより被検個体 の関心がそちらに移り，検查の続行が不可能となったた めである。さらに, 眼底所見が正常な個体に比べて, 黄 斑変性を呈する個体の視覚機能は明らかに劣っていた。 しかも, 黄斑変性の程度に応して, 視覚機能の差もわず かながら存在することが示唆された。一方，非中心性網 膜変性所見を呈する個体の視覚機能は眼底所見が正常な 個体とほぼ同様であった。これらの差をさらに明確にす るには, 今後, 黄斑変性, 非中心性網膜変性を呈する個 体の検查例数を増して検討することや，網膜活動電位、 視覚誘発電位等の測定法を併用することが必要である。

\section{要 約}

光透過率が異なる面を着用した観察者の眼に対する, カニクイザルの凝視反応を利用する視覚判定のための簡 単な方法（鉿木ら，1988）を，黄斑変性および非中心性 網膜変性を示す個体に適用し，眼底所見が正常な個体と 比較した。その結果, 眼底の正常な個体に比べて, 黄斑 変性を呈する個体の視覚機能は明らかに劣っていた。さ らに, 黄斑変性の程度に応した視覚機能の差も認められ た。一方, 非中心性網膜变性所見を呈する個体の視覚機 能は眼底所見が正常な個体とほぼ同様であった。

\section{文嗝}

[1] Bisrner, S. I. (1971). Examination of the eye. Vet. Clin. North Amer., 1, 29-51.

[2] Gelatt, K. N. (1981). Ophthalmic Examination and Diagnostic Procedures. In Textbook of Veterinary Ophthalmology, pp. 206-261, Gelatt, K. N. (edit.) Lea \& Febiger, Philadelphia.

［3］本庄重男（1979）。カニクイザル，実験動物の飼育管理 
と手技（高橋和明・信永利馬編），pp.415-433，ソフト サイェンス社, 東京.

[4] Honjo, S. (1985). The Japanese Tsukuba Primate Center for Medical Science (TPC): An outline, $J$ Med. Primatol, 14, 75-89.

［5］金子洋二・三枝 雅・佐藤利和・奈良間 功 (1980). 生殖試験におけるラットを用いた視覚異常の簡易検出 法. 実験動物，29，397-400.

［6］三枝 雅・金子洋二・奈良間 功 (1984). 生殖試験に おけるラットを用いた視覚異常の簡易検出法 : 臨界照度 および暗順応効果. 実験動物, 33,181-185.

[7] 室伏靖子 (1985). 行動研究の方法. 霊長類学入門（江 原昭善・大沢 済・河合雅雄・近藤四郎編)，pp. 172178. 岩波書店, 東京。

［8］仁田正雄 (1977). 眼疾患検查法. 眼科学, pp. 181-235. 文光堂, 東京。

［9］鈴木通弘・成田勇人・長 文昭・本庄重男（1983）。実 験用カニクイザルの眼底像 -0 日齢より19歳龄にいた る各齡での所見一。比較眼科, 2, 21-26.

［10］鈴木通弘・成田勇人 - 田中吉春・長 文昭・福井正信 (1984）. 䒠験用カニクイザルの眼底像 一新生仔期およ び乳仔期における所見一。実験動物，33．173-179.
［11］鈴木通弘・成田勇人・福井正信（1985）。カニクイザル において観察された瞳孔膜遺残例について。実験動物， 34. 81-84.

［12］鈴木通弘・成田勇人・長 文昭・福井正信・本庄重男 （1985）. 実験用カニクイザルの眼底像一㕕成ザルにみ られた異常所見一。実験動物, 34. 131-140.

［13］鈴木通弘・成田勇人・羽成光二・福井正信 - 長 文昭・ 本庄重男（1986）．カニクイザルにおいて観察された先 天性白内障例について。実験動物, 35. 193-197.

［14］鈴木通弘・長 文昭 (1986). 霊長類（カニクイザルを 中心に)の検査法の実際とその問題点. J. Toxicol Sci, 11. $444-455$.

[15] Suzuki, M. T., Hiyaoka, A., Cho, F., and Fukui, M. (1988). Some cases of cataract in the African green monkeys Anim Eye Res., 7. 27-29.

［16］鈴木通弘・小川浩美・福开正信・長 文昭・本庄重男 (1988).カニクイザルの視覚判定のための簡単な方法の 検討. 霊長類研究, 4. 114-120.

[17］高橋和明・斎藤 徹・三森国敏・田内清憲 $(1980)$ 。検 査法(検査方法と異常例). 薬物と感覚障害（中島 章・ 秋吉正豊編)，pp. 20-51。ソフトサイエンス社, 東京. 